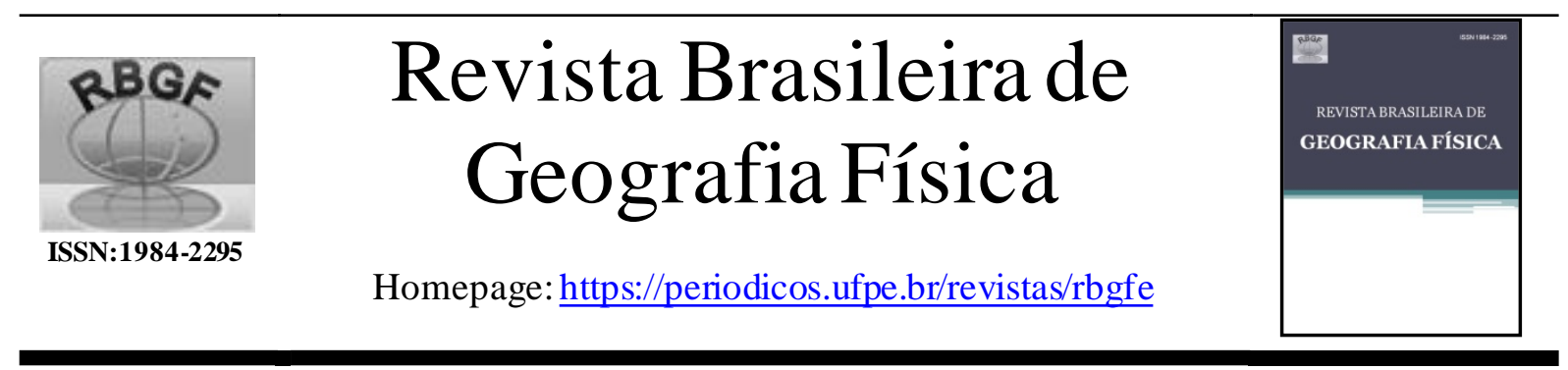

\title{
Spatiotemporal variability of Humidex Index over the Northeast Region of \\ Brazil
}

\author{
Wanda Tathyana de Castro SILVA ${ }^{1}$, Georgenes Hilário CAVALCANTE²
}

\begin{abstract}
${ }^{1}$ Mestrandaem Meteorologia; Universidade Federal de Alagoas, Instituto deCiências Atmosféricas, Campus A. C. Simões, Cep: 57072 -970, Tabuleiro do Martins, Alagoas, Brasil. (82)3214-1000, wandatathyana@gmail.com (autor corres pondente), ${ }^{2}$ Dr. Georgenes Hilário CAVALCANTE. Programa de Pós-Graduação em Meteorologia (PGMET). Professor Orientador, Instituto de Ciências Atmosféricas, Campus A. C. Simões, Cep : 57072-970, Tabuleiro do Martins, Alagoas,Brasil. (82)3214-1000, georgenes.cavalcante@icat.ufal.br
\end{abstract}

Artigo submetido em 18/05/2021 e aceite em 16/06/2021

\section{R E S U M O}

O conforto térmico, Humidex, é uma variável muito importante para a valiar o grau de estresse térmico em seres vivos. Por depender de variáveis climáticas, o Humidex tem uma variação espaço-tempo-intensidade condicionada a vários atenuadores do tempo e do clima. Assim, o objetivo deste trabalho é verificar possíveis tendências e a nálises espaço temporais do índice Humidex no Nordeste do Brasil (NEB). Foram utilizados os dados do ERA5 distribu ídos pelo ECMWF para o período de 1990 a 2019. Constatou-se que a região do MATOPIBA foi a que mais se destacou com tendências positivas de desconforto sobre o NEB, assim como a região com os maiores índices Humidex. Enquanto na costa do NEB havia vales baixos de Humidex que podem estar associados à influência oceânica. Observou -se que o período noturno tem tendência positiva no NEB, principalmente no MATOPIBA. Além da escala horária, consta tou -se também que na escala mensal, sazonal e anual, esta região do MATOPIBA tem destaque. Isso se deve ao fato da substituição da floresta natural pela produção a grícola, na qual, afeta diretamente o balanço energético de sta re giã o. A região de MATOPIBA apresentou as maiores tendências de temperatura em NEB com taxa positiva variando de $+0,008^{\circ} \mathrm{C} /$ Hora $/$ Mês a $0,01^{\circ} \mathrm{C} /$ Hora/Mês. A tendência sazonal de umidade foi marginal apenas na região costeira, com valores máximos variando entre $0,01^{\circ} \mathrm{C} /$ ano e $0,02{ }^{\circ} \mathrm{C} /$ ano. Aproximadamente $2,41 \%$ do NEB apresentou tendência igual ou superior a $+0,06{ }^{\circ} \mathrm{C} / \mathrm{Anno}$ e $24,21 \%$ do NEB com tendência igual ou superior a $+0,05^{\circ} \mathrm{C} / \mathrm{Ano}$. Tendência sazonal positiva de $+0,04^{\circ} \mathrm{C} /$ ano foi observada na bacia do rio São Francisco. Verificou-se que o período de La Niña foi termicamente mais confortá vel, contrário a o El Niño. A redução/aumento da precipitação no NEB devido ao El Niño/La Niña levaram à a tenuação do índice Humidex, a lém das altereções devido à modificação do uso do solo.

Palavras-chave: clima, atmosfera, conforto térmico, matopiba.

\section{Spatiotemporal variability of Humidex Index over the Northeast Region of}

\section{Brazil}

\begin{abstract}
A B S T R A C T
Thermal comfort, Humidex, is a very important variable to assess the degree of thermalstress on living beings. Because it depends on climatic variables, Humidex has a space-time-intensity variation conditioned to various weather and climate attenuators. Thus, the objective of this work is to verify possible trends and spatiotemporal analysis of the Humidex index on the Northeast of Brazil (NEB). ERA5 data distributed by ECMWF was used for the period from 1990 to 2019. It was found that the MATOPIBA region was the one that stood out the most with positive discomfort trends over NEB, as well as the region with the largest Humidex indexes. While on the NEB coast there were low Humidex valleys which may be associated with oceanic influence. It was observed that the night time has a positive trend on NEB, especially on MATOPIBA. In addition to the hourly scale, it was also found that on the monthly, seasonal and annual scale, this region of MATOPIBA has a highlight. This is due to the fact that the replacement of the natural forest by agricultural production, in which, it directly affects the energy balance in this region. MATOPIBA
\end{abstract}


region presented the highest trends on temperature in $\mathrm{NEB}$ with a positive rate varying from $+0.008^{\circ} \mathrm{C} / \mathrm{Hour} / \mathrm{Month}$ to $0.01^{\circ} \mathrm{C} /$ Hour/Month. The seasonal humidex trend was only marginal the coastal region, with only few areas with maximum values of $0.01{ }^{\circ} \mathrm{C} /$ Year to $0.02{ }^{\circ} \mathrm{C} /$ Year. Approximately $2.41 \%$ of the NEB shows a trend equal to or greater than $+0.06^{\circ} \mathrm{C} /$ Year and $24.21 \%$ of the NEB with a trend equal to or greater than $+0.05^{\circ} \mathrm{C} /$ Year. The increased seasonal trend observed in the São Francisco river basin was $+0.04^{\circ} \mathrm{C} /$ Year. The La Niña period was considered thermally comfortable, contrary to the El Niño period. The reduction and increase in precipitation on the NEB due to El Niño and La Niña led to the attenuation of the Humidex index, similarly, changes on land use did played a role modifying the Humidex index.

Keywords: climate, atmosphere, thermalcomfort, Matopiba.

\section{Introduction}

Temperatures outside a comfort range affect the human health and are related to increased stress and mortality. Reports of the various Brazilian professional organizations (CPTEC, INPE) shows that global warming causes climate change expressed for example by the temperature increasing. In Brazil, and particularly, its Northeast region (NEB), the mean temperature has been increasing $25 \%$ f as ter than the global average since 1910, implying that the population may be particularly exposed to the effects of increasing temperature relative to other populations (NOAA, 2017), posing risks for human health. In these circumstances, knowledge of the conditions of thermal discomfort it is necessary, especially in areas with high mortality risk due to excessive temperatures. The thermal comfort is difficult to be quantified because it is necessary to consider a range of environmental and human factors to decide what makes a pers on to feel thermal comfortable. The first factors can include air temperature, radiant temperature, wind speed and air humidity, while the later are attributed to so called "metabolic heat" (Brake and Bates, 2003).

According to World Health Organization, the continuous exposure of an individual to an environment whose thermal conditions are adverse to those he is accustomed causes the organism to undergo physiological changes to adapt to the environment (Buitrago et al., 2016). This is particularly important, as heat-wave episodes are became more frequent and may cause hyperthermia, dehydration, and respiratory diseases. In the other hand, extreme cold temperatures can result in ischemic heart, cerebrovascular, and respiratory diseases (Schwarz et al., 2010).

As global models predict significant changes in the climate of the NEB regions, it is expected that the increased temperature would directly affect the well-being of the population, since the variations of air temperature, precipitation, relative humidity, and wind speed are highly important when quantifying the thermal comfort of a region. More importantly, the NEB is exposed to several weather and climate attenuating systems that can lead to an increase in the level of comfort or thermal discomfort such as the Intertropical Convergence Zone (ITCZ), Breezes, High Level Cyclonic Vortexes (HLCV), stability lines, convective systems, wave disturbances, and less frequently, tropical cyclones (Hastenrath and Heller, 1977; Kousky and Gan, 1981; Molion and Bernardo, 2002; Fedorova et al., 2009; Rodrigueset al., 2010; Fedorova et al. , 2020). In addition, in El Niño/La Niña years, the precipitation regime decreases/increases in the Brazilian Northeast (NEB) and increases/decreases in the south region of Brazil (Grimm et al. 1998).

In that sense, as the climate conditions in the NEB tends to be worsening due to various phenomena at different spatiotemporal scales such changes will cause discomfort in the NEB population, and may require adaptation of the organism during these periods. In that sense, this study is an efforts to assess the degree of thermal comfort evaluate throughout the NEB based on Humidex index estimations. Evaluating the spatiotemporal variability of the indices and ocean-atmosphere forcings, will help to identify the potential correlation between external forcing and thermal conditions within the region.

It is known that the interaction between climate, weather and city configuration is complex (Darbani, et al., 2021; Matallah, et al., 2021; Pereira and Bourscheid). According to Pereira and Bourscheid (2021) although people who live in buildings located near the sea are also exposed to high temperatures, the fluctuation remains in a range classified as comfortable, mainly due to the shading and the sea breeze. However, the growth of cities has increased thermal discomfort due to the replacement of vegetation by concrete among other factors (Sharma et al., 2021). According to Meili et al. (2021) the increase in humidity due to vegetation restricts was regarded as the factor responsible for the reduction of the thermal average to $3{ }^{\circ} \mathrm{C}$, as 
well as, urban growth has an negative effect on thermal comfort microclimate (Darbani, et al., 2021). That been said, urban developments should develop strategies that seek mitigation and adaptation, taking advantage of the existing green infrastructure (Matallah, et al., 2021, Meili et al., 2021).

In that sense, this study focusing on understand the spatiotemporal trends of the Humidex index over the NEB, taking in consideration, how the change in land use can impact the thermal comfort indices? How does the land-ocean-atmosphere interaction may impact the Humidex indices?

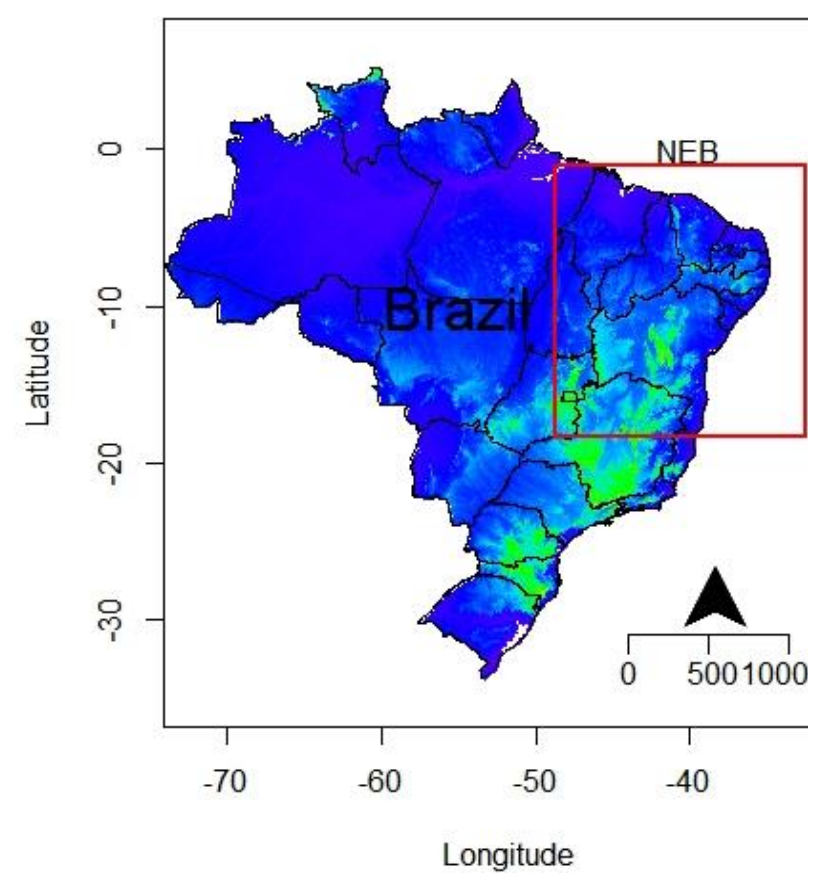

Figure 1- Brazil and study area in red. Altimetry is represented by the colorbar.

\section{Dataset}

For this study, the ECMWF Global Reanalysis database, ERA5, was used, with a grid spacing of $0.25^{\circ} \times 0.25^{\circ}$ (Latitude-Longitude) (Hersbach, 2017; Hersbach et al., 2019; Hersbach et al., 2020). The Humidex index was used to calculate air temperature and dew point temperature, measured every hour ( 2 meters height), during the period 1990-2019 (30 y ears). This database has been used in several areas and research (Cucchi et al., 2020; Di Napoliet al.,

\section{Material and Methods}

\section{Location}

The NEB region $(53,081,950$ inhab.) consists of nine states: Alagoas $(3,120,494$ inhab.), Bahia (3,120,494 inhab.), Ceará $(8,452,381$ inhab.), Paraíba (3,766,528 inhab.), Pernambuco (8,796,448 inhab.), Piauí (3,118,360 inhab.), Rio Grande do Norte (3,168,027 inhab.), Maranhão $(6,574,789)$ and Sergipe $(2,068,017$ inhab.) (IBGE, 2020). It occupies an area of $1,554,000 \mathrm{~km}^{2}$, about $18.27 \%$ of the Brazilian territory (Figure 1).

2020; Li, 2020; Martens et al., 2020; Mistry, 2020; Tarek et al. 2020; Vitolo et al., 2020).

\section{Humidex Index}

The calculation of the Humidex index was based on the methodology adopted by Thom's (1959) and d'Ambrosio Alfano et al (2011), and are expressed in the equations below:

$$
\text { Humidex }=T+\frac{5}{9}\left(p_{a s}-10\right)
$$

Where,

$$
p_{a s}=6.112 .\left(10^{7.5}\left(\frac{T}{237.7+T}\right)\right) \frac{R H}{100}
$$

To calculate the relative humidity $(\mathrm{RH})$, the dry bulb $(T)$ and wet $\left(T_{d}\right)$ temperature were used according to equation (3) from ERA5. RH corresponds to the ratio of the actual vapor pressure $\left(e_{a}(\mathrm{~T})\right)$ and saturation $\left(e_{s}\left(T_{d}\right)\right)$ at the same temperature, in percentage:

$$
R H=100 \frac{e_{a}(T)}{e_{s}\left(T_{d}\right)}
$$

The actual vapor pressure $\left(e_{a}(\mathrm{~T})\right)$ and the saturation pressure $\left(e_{s}\left(T_{d}\right)\right)$ were calculated from equations (4) and (5):

$$
e_{a}(T)=e_{s}\left(T_{0}\right) \exp \left(\frac{L}{R_{w}}\left(\frac{1}{T_{0}}-\frac{1}{T}\right)\right)
$$




$$
e_{s}\left(T_{d}\right)=e_{s}\left(T_{0}\right) \exp \left(\frac{L}{R_{w}}\left(\frac{1}{T_{0}}-\frac{1}{T_{d}}\right)\right)
$$

Where, $e_{a}(T)$ and $e_{s}\left(T_{d}\right)$ correspond to the actual vapor pressure at temperature $\mathrm{T}$, and vapor saturation pressure at temperature $T_{d}$, respectively. $\left.e_{S}\left(T_{0}\right)\right)$ is the vapor saturation pressure at a reference temperature $T_{0}, L=$ $2.5 \times 10^{6} \mathrm{~J} / \mathrm{kg}$ corresponds to the latent heat of water evaporation and $R_{w}=\frac{1000 R}{M_{w}}=$ $461.52 \mathrm{~J} / \mathrm{kgK} . R=8.3144621 \mathrm{~J} /(\mathrm{molK})$ is the gas molar constant and $M_{w}=18.01528 \mathrm{~g} / \mathrm{mol}$ is the molecular weight of water vapor. The reference temperature and vapor saturation pressure used were $T_{0}=273,15 \mathrm{~K}$ and $e_{S}\left(T_{0}\right)=$ $6,11 \mathrm{mb}$.

The Humidex limits and the thermal comfort index are shown in Table 1.

\begin{tabular}{|c|c|}
\hline $\begin{array}{l}\text { Humidex } \\
\text { range }\end{array}$ & Thermal discomfort level \\
\hline $29 \leq$ Hum $\leq 20$ & Comfort \\
\hline $39 \leq$ Hum $\leq 30$ & Some discomfort \\
\hline $45 \leq$ Hum $\leq 40$ & $\begin{array}{l}\text { Great discomfort, avoid } \\
\text { exertion }\end{array}$ \\
\hline
\end{tabular}

\section{$\mathbf{5 4} \leq$ Hum $\leq 46 \quad$ Dangerous}

$<\mathbf{5 4}$ Heat stoke iminente

Table 1- Limit values and ranges of Humidex index corresponding to the increase in thermal discomfort conditions (Masterton JM, Richardso n FA, 1979); d'Ambrosio Alfanoet al., 2011)

\section{Mann-Kendall test}

To calculate the Humidex trend on the hourly, monthly, seasonal and annual scale, the Mann-Kendall (MK) non-parametric statistical test was used (Mann, 1945; Kendall, 1975). The S statistic is obtained by the sum of all counts, where the sign $\left(x_{i}-x_{j}\right)$ is determined by (6):

$$
S=\sum_{i=2}^{n} \sum_{j=1}^{i-1} \operatorname{sgn}\left(x_{i}-x_{j}\right)
$$

The MK test analyses data collected over time for consistently increasing or decreasing trends. The test gives one of two options: null hypothesis (no monotonic trend in the series) or alternative hypothesis (there is a trend and it can be positive, negative or null). The variance obtained from the MK statistic is used to define the value for a specific significance level.

The humidity package (Cai, 2019) was used to calculate the relative humidity of the air. The Humidex index was calculated from the Thermindex package (Castelhano, 2017). For the colors, the RColorBrewer package was used (Neuwirth, 2014.). For the interpretation of the ERA5 nectdf files, the raster pack age (Hijmans, R.J., 2020) and rasterVis (Lamigueiro and Hijmans, 2020) were used. For trend calculations, the trend (Pohlert, 2020), spatialEco (Evans, 2020) and greenbrown (Forkel et al., 2013; Forkel et al., 2015) packages were used. To interpret these algorithms, the program R (R, 2020) was used.

\section{Results and Discussion}

\section{Hourly and Monthly Climatology of the Humidex Index}

Figure 2 shows the spatiotemporal average of the Humidex indices for the NEB region from 1990 to 2019. It is observed that the thermal comfort index increases from $30^{\circ} \mathrm{C}$ to 24 ${ }^{\circ} \mathrm{C}$ between $22 \mathrm{Z}$ (19h local) to $10 \mathrm{Z}$ (07h local), night time to middle morning period, following the decrease of air temperature $\left(24^{\circ} \mathrm{C}\right.$ to $\left.36^{\circ} \mathrm{C}\right)$. Such pattern is more prominent over regions with high altitude such as the Chapada Diamantina region located over the central region of Bahia. Meanwhile, during daytime ( 8 am local time) to later afternoon (6 pm local time) period it was found peak Humidex indices of $39^{\circ} \mathrm{C}$ on Maranhão and Piauí regions which is correspondent to greatest discomfort according to Humidex classification, lasting for about 10 hours, on average. 


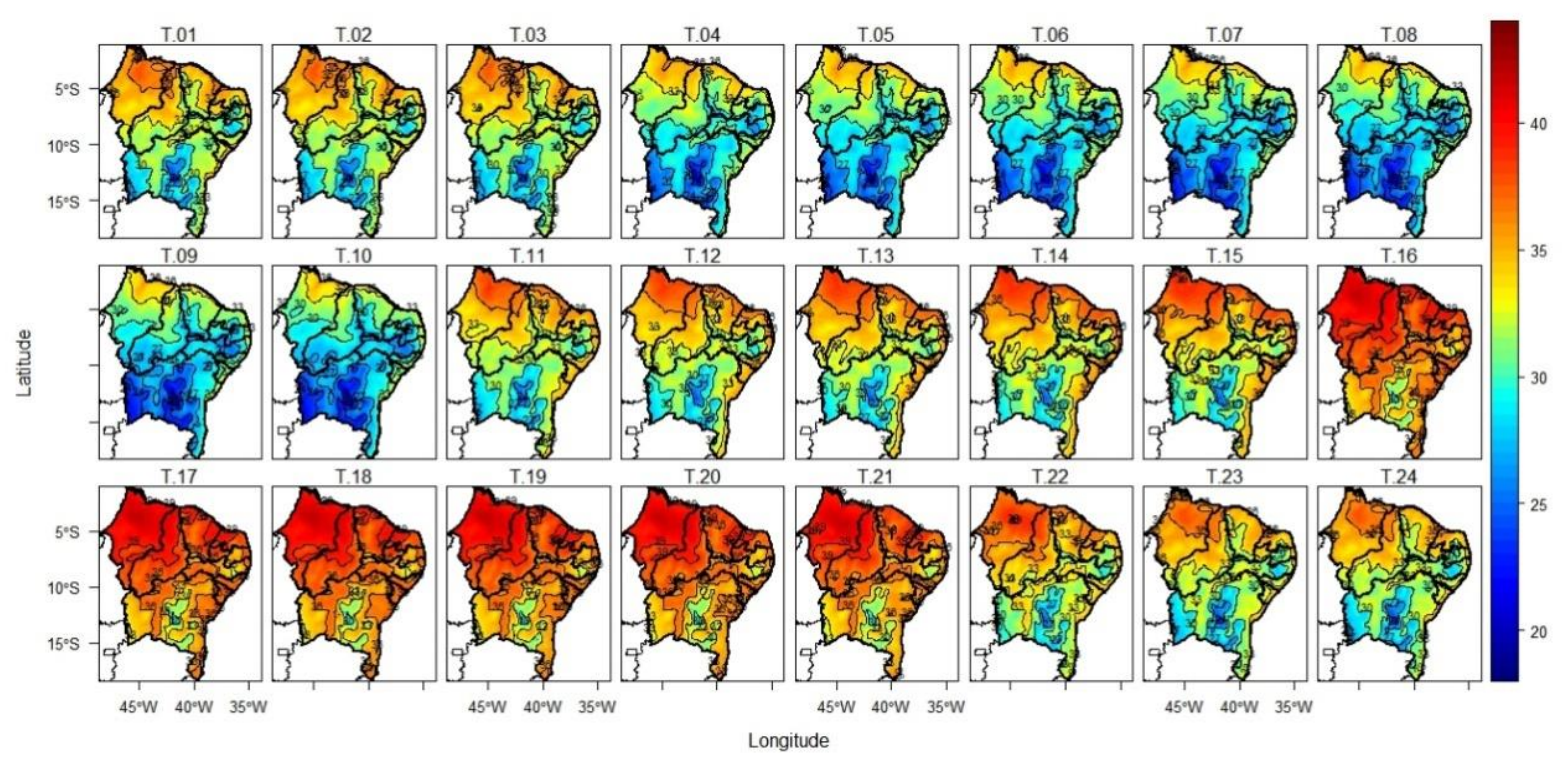

Figure 2 - Hourly climatology of the Humidex index from 1990 to 2019.

According to the Humidex index, regions located at $5^{\circ} \mathrm{S}$ latitude revealed indexes above $35^{\circ} \mathrm{C}$ from October to May. It was found th at the areas near the coast has a relatively constant index throughout the year. Can is associated with the influence of the ocean as a source of heat and humidity on the coast.

It was observed that between $10{ }^{\circ} \mathrm{S}$ to 20 ${ }^{\circ} \mathrm{S}$ the Humidex index declines from January (29 ${ }^{\circ} \mathrm{C}$ ) to August $\left(>23^{\circ} \mathrm{C}\right)$, mainly on the Chapada Diamantina and central region of the state of Bahia as well as in other regions of high altitudes such as in Pernambuco, Alagoas and Paraíba. This can be attributed to the position of the sun, altitude and weather and climate factors. For instant, studies showed that during El Niño, cold fronts are less frequent in the region inhibiting rainfall, and the other hand, La Niña is characterized by frequent cold fronts inducing intense rainfall and lower air temperature (Pereira et al., 2011).
Despite the temporal variability of precipitation that influences the energy balance, the NEB region reveals a constant energy balance throughout the year. According to Correia Filho et al (2019) they showed that the rainy season in the Amazon, Caatinga and Cerrado biomes occur between January and April, but varying in intensity, not seen in the Atlantic Forest. The regions with greatest comfort levels were Bahia and Pernambuco with value of $26{ }^{\circ} \mathrm{C}$ to $23{ }^{\circ} \mathrm{C}$ during May to September (Figure 3). Correia Filho et al (2019) show that the extreme south of the Caatinga, Cerrado and Atlantic Forest are influenced by frontal systems and, consequently, influence the elevated thermal comfort levels in the region. 

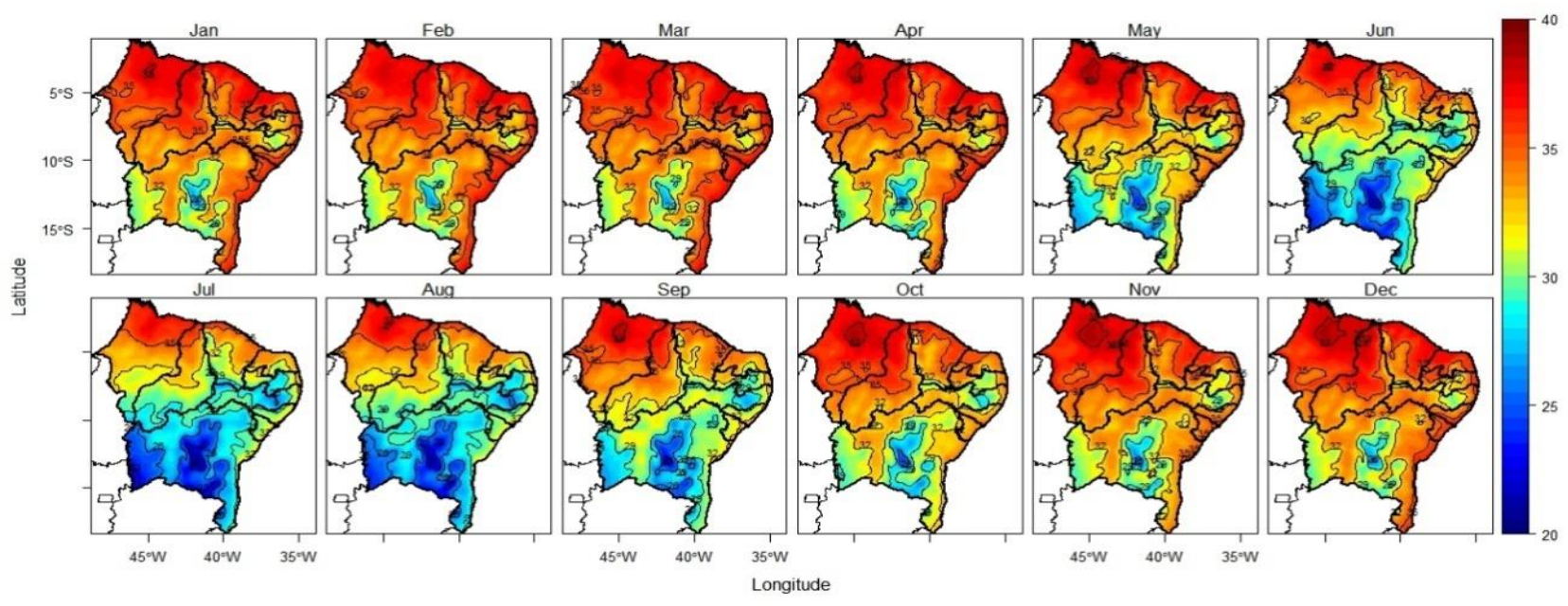

Figure 3 - Monthly Climatology of the Humidex index from 1990 to 2019.

\section{Hourly, Monthly, Seasonal and Annual Trend of the Humidex index}

It can be seen that Figure 4 shows that the positive hourly trend occupies a large part of the NEB region. During the night time period (22Z to 04Z), the MATOPIBA region (Figure 4, T.22 to T.04), presented the highest trends on temperature in NEB with a positive rate varying from $+0.008^{\circ} \mathrm{C} /$ Hour $/$ Month to $0.01^{\circ} \mathrm{C} /$ Hour $/$ Month On the coast region, there is a slight negative trend during the night time period, which may be associated with increased sea breeze intensity and local precipitation. Studies have shown that sea breeze winds have significant cooling potential, impacting thermal comfort levels (He et al., 2020a, He et al., 2020b, Liu et al., 2020).

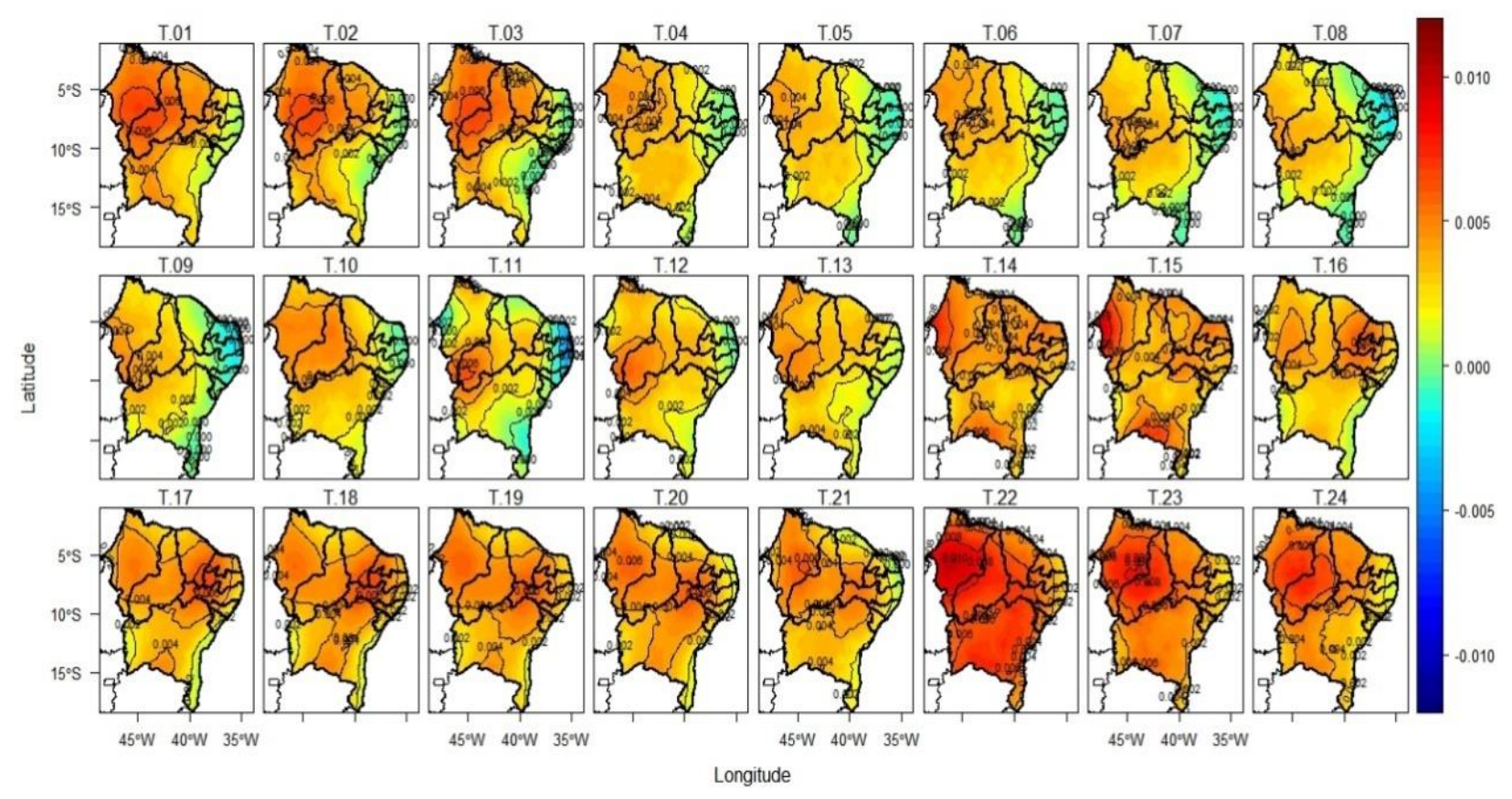

Figure 4- Hourly trend of the Humidex index from 1990 to 2019.

The monthly Humidex index trend is shown in Figure 5. Again, the MATOPIBA region reveals a very significant trend varying from $+0.04^{\circ} \mathrm{C} /$ month to $+0.08^{\circ} \mathrm{C} /$ month, mainly in
March, October and November. The small Humidex trends are seen in the coastal region which may be associated with oceanic influence (Moura et al., 2009; de Medeiros et al., 2020). 

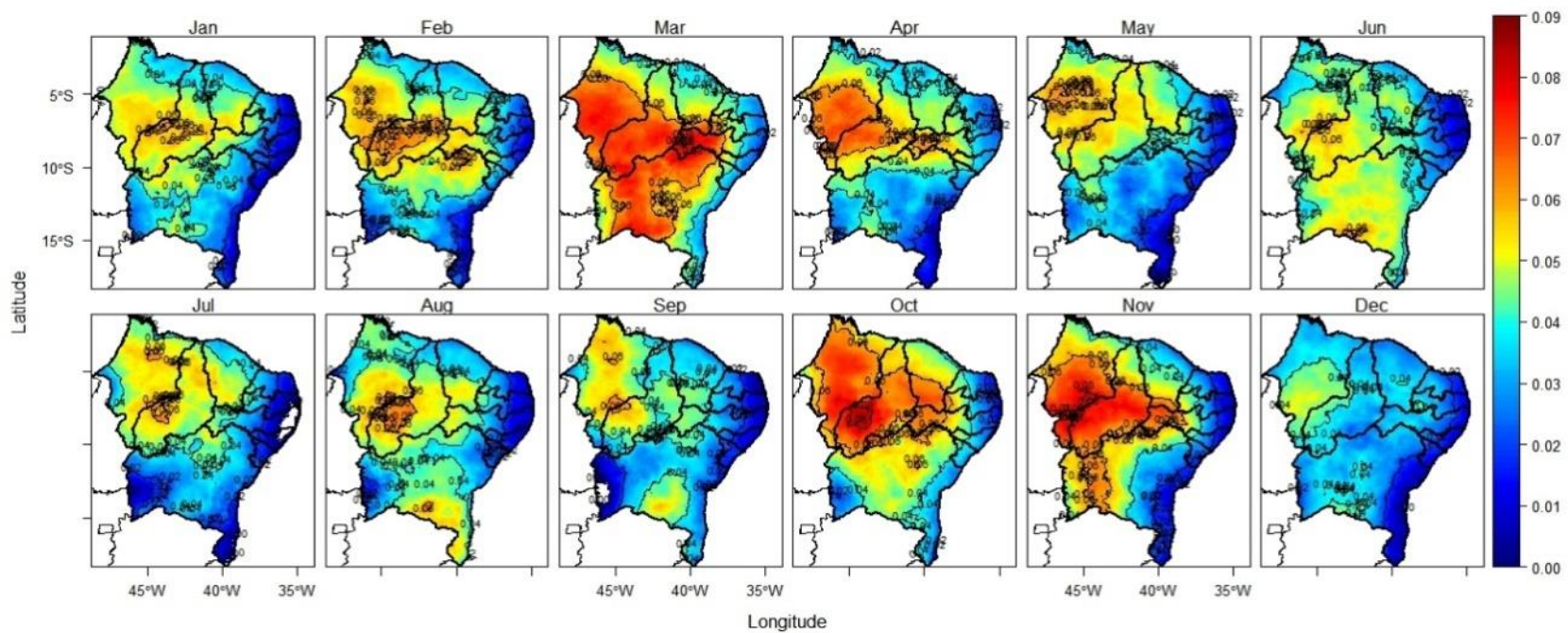

Figure 5- Monthly trend of the Humidex index from 990 to 2019.

An increasing seasonal trend is observed throughout a large area covering the NEB region (Figure 6). The states of Maranhão and Piauí registered trends exceeding $+0.06{ }^{\circ} \mathrm{C} /$ month. Approximately $2.41 \%$ of the NEB shows a trend equal to or greater than $+0.06{ }^{\circ} \mathrm{C} /$ Year and $24.21 \%$ of the NEB with a trend equal to or greater than $+0.05^{\circ} \mathrm{C} /$ Year. The increased seasonal trend observed in the São Francisco river basin $+0.04^{\circ} \mathrm{C} /$ Year and MATOPIBA (Figure 6) can be attributed to the change in land use with intensification of soybean and other agricultural crops, causing a direct effect on the local and regional climate. According to Cunha et al. (2015a), they showed that changes in land cover influenced the climate processes at a large scale due to the changes in surface energy and carbon balance. Moreover, Angelini et al. (2017) showed that the latent heat flow in the Cerrado may reach levels $60 \%$ higher than in agronomic crops, while the sensitive heat flow can increase up to $50 \%$ higher in agricultural areas compared to Cerra do areas. Overall, these results play a role on the cause-effect of replacing vegetation, and observed thermal discomfort increase in the study region. The seasonal humidex trend was only marginal the coastal region, with only few areas with maximum values of $0.01{ }^{\circ} \mathrm{C} /$ Year to $0.02^{\circ} \mathrm{C} /$ Year.

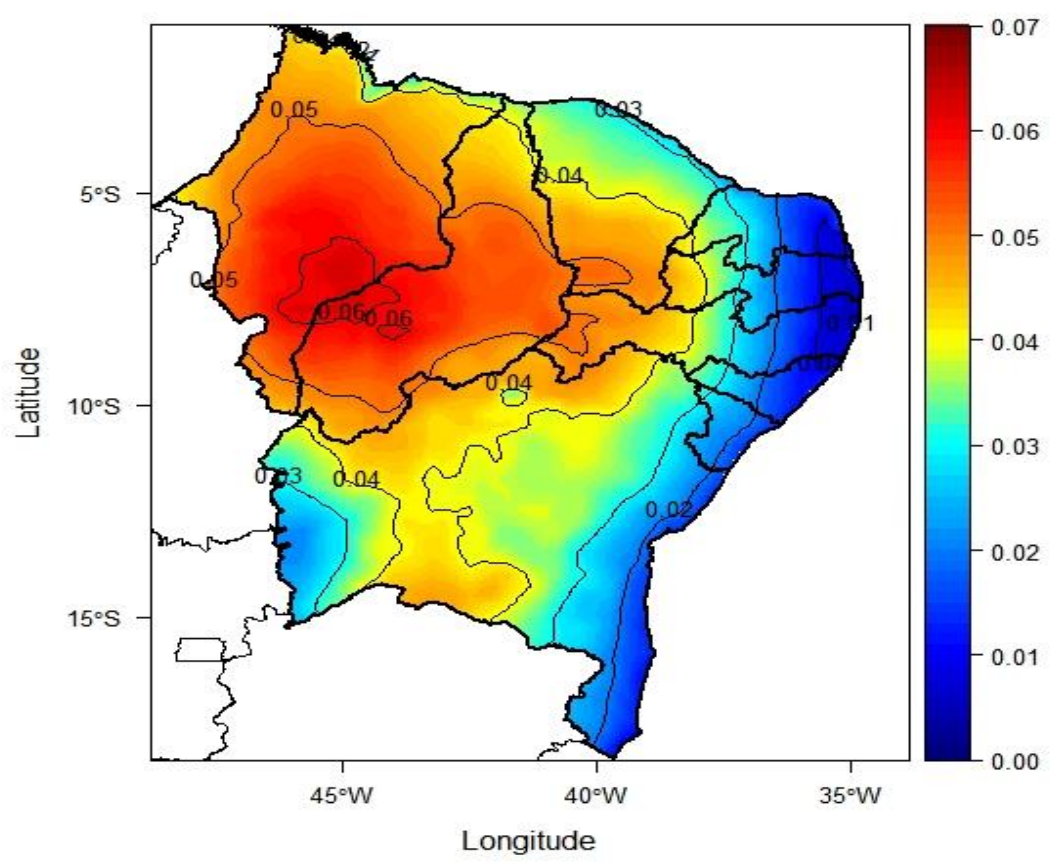

Silva, W. T. C., Cavalcante, G. H. 
Figure 6- Seasonal trend of the Humidex index from 1990 to 2019.

The annual trends showed a similar variability compared to the seasonal, where the later indicated values exceeding $0.06^{\circ} \mathrm{C} /$ Year, and more intense in the Maranhão and Piauí states (Figure 7). Approximately $3.13 \%$ of the NEB shows a trend equal to or greater than 0.06 ${ }^{\circ} \mathrm{C} /$ Year, expanding to $26.57 \%$ of the NEB with a trend equal to or greater than $0.05^{\circ} \mathrm{C} /$ Year. This represents an increase of $1.8{ }^{\circ} \mathrm{C}$ to $1.5{ }^{\circ} \mathrm{C}$, respectively, in 30 years. Again, the change in land use directly affects the energy balance, rainfall and air temperature in the region (Narisma et al., 2003; Cunha et al., 2015a; Hirota et al., 2011; Angelini et al., 2017, Gaspari et al., 2018 ; Salvador et al. 2018; Silva et al., 2018; Cabral Júnior et al. 2019; Marçalet al., 2019).
According to Costa et al. (2020) the NEB region shows unmistakable signs of warming, in which, in the last decades, there have been predominant tendencies for a decrease in the percentage of cold nights ( $-8.4 \%$ days/decade), an increase in the number of hot nights $(10.6 \%$ days/decade), as well as in the number of days per decade in which the minimum temperatures exceeded the threshold of $20^{\circ} \mathrm{C}$, and a tendency to increase heat waves events. These changes are due to some factors that, according to Carvalho et al. (2020) are related to the reduction in the number of precipitation/days, mainly along the coastal zone, as well as reduction in precipitation rate within 150 to $300 \mathrm{~km}$ from the coast, and in the Sertão region (Vieira et al., 2020; Marengo et al., 2020).

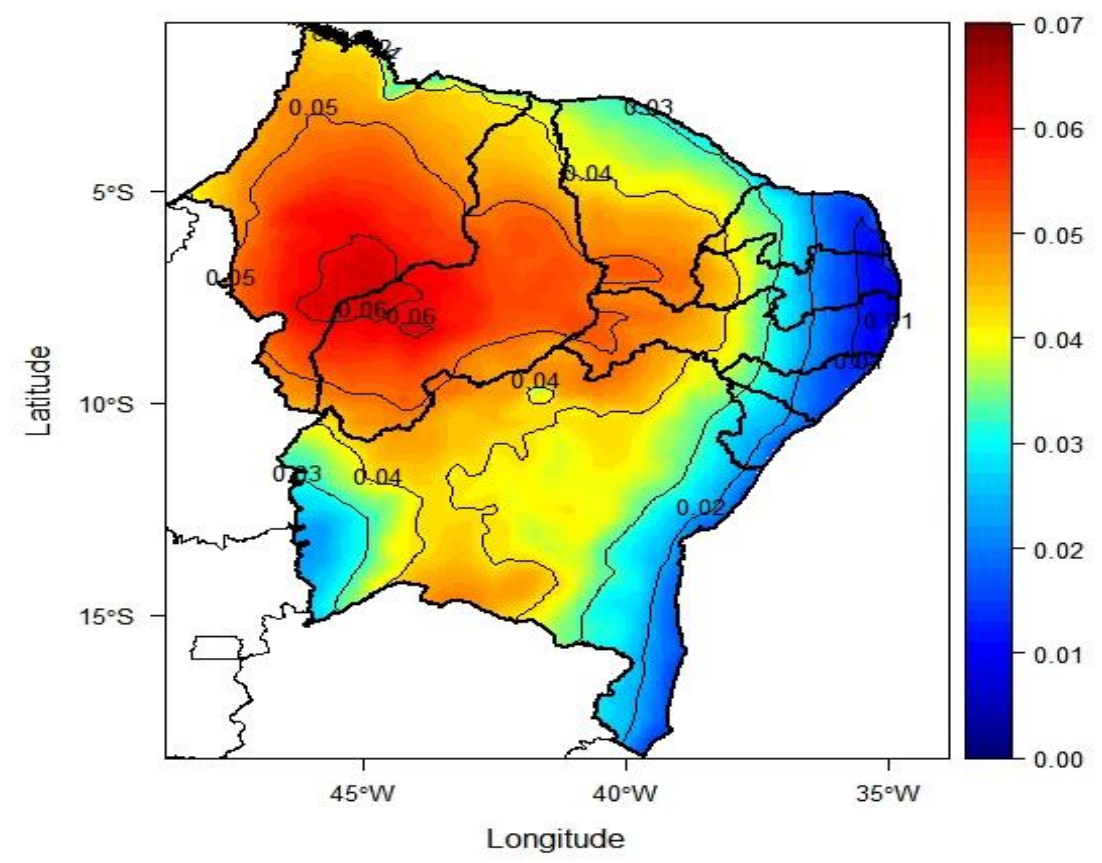

Figure 7-Annual trend of the Humidex index for 1990 to 2019.

In addition to climatic factors, the change in land use with replacement of native vegetation by soy has altered the energy balance. According to Vieira et al. (2021), they showed that approximately $4677 \mathrm{~km}^{2}(0.63 \%)$ of MATOPIB A region is under strong signs of degradation, mainly in pasture areas and fields, commonly used for pasture. Consequently, in addition to the gradual replacement of native vegetation, solar radiation directly affects the soil, further warming this region.

Table 2 shows that minimum $30.4^{\circ} \mathrm{C}$ and maximum $39.6{ }^{\circ} \mathrm{C}$ values of Humidex index (HI) were found in Maceió/AL and Teresina/PI, respectively, while peak average of $36.7{ }^{\circ} \mathrm{C}$ was found in Teresina/PI. Annual HI trends were statistically significant throughout the cities with the exception of João Pessoa/PB and Recife/PE, and indicates an overall positive tendency (Table 2 ). The highest annual trends were on cities located in the northern sector of NEB, represented by the city Balsas/MA with $0.061^{\circ} \mathrm{C} /$ Year.

According to studies performed by Salvador and Brito (2018) the maximum and minimum temperatures and the extreme temperature indexes showed a strong positive 
trend in practically all series $(\mathrm{p}<0.05)$ over the MATOPIBA region, Maranhão state, Tocantins, Piauí and Bahia. The authors also pointed out that this region has been under a significant warming process in the last 3 decades.

Table 2 - Descriptive statistics and annual Humidex index (HI) trends with respective p-values according to Mann-Kendall test for capital state cities of NE Brazil, and Balsas City representing the northern sector of $\mathrm{NE}$ region. Unit values are in ${ }^{\circ} \mathrm{C}$.

\begin{tabular}{lcccccc}
\hline City & Min & Max & Mean & \pm std & $\begin{array}{c}\text { Trend } \\
{ }^{\circ} \mathrm{C} / \mathrm{Yr}\end{array}$ & $\mathrm{p}$-value \\
\hline São Luís/MA & 35.5 & 39.4 & 37.2 & 0.6 & +0.031 & 0.001 \\
Teresina/PI & 32.8 & 39.6 & 36.7 & 0.8 & +0.048 & 0.000 \\
Fortaleza/CE & 33.6 & 39.4 & 36.4 & 0.6 & +0.031 & 0.000 \\
Natal/RN & 32.1 & 38.9 & 35.4 & 0.5 & +0.016 & 0.030 \\
João Pessoa/PB & 31.7 & 39.0 & 35.3 & 0.5 & +0.012 & 0.103 \\
Recife/PE & 30.8 & 38.5 & 34.7 & 0.6 & +0.009 & 0.253 \\
Maceió/AL & 30.4 & 38.0 & 34.2 & 0.5 & +0.015 & 0.050 \\
Aracaju/SE & 30.5 & 38.2 & 34.4 & 0.6 & +0.017 & 0.043 \\
Salvador/BA & 29.3 & 39.0 & 34.3 & 0.8 & +0.023 & 0.027 \\
Balsas/MA & 30.1 & 38.1 & 34.5 & 0.9 & +0.061 & 0.000 \\
\hline
\end{tabular}

The annual evolution of Humidex and the soybean cultivation areas in the municipalities of Balsas/MA and Tasso Fragoso/MA are the largest soybean producers in this region (Figure 8 ). The results indicate that the growing trend of environmental discomfort is associated with the increase in soybean cultivation on Balsas and Tasso Fragoso (Figure 8). These two municipalities are the largest producers of soybeans in the state of Maranhão.

We applied pearson's correlation between the Humidex index and the soybean area in both municipalities and found correlations of $0.82(\mathrm{p}=$ $2.879 \mathrm{e}-08)$ (Balsas) and $0.83(\mathrm{p}=1,101 \mathrm{e}-08)$ (Tasso Fragoso), which confirms that the gradual replacement of natural vegetation by soy reflected positively on the thermal discomfort over the region of Maranhão and Piauí at approximately 2 ${ }^{\circ} \mathrm{C}$ (Figure 8).

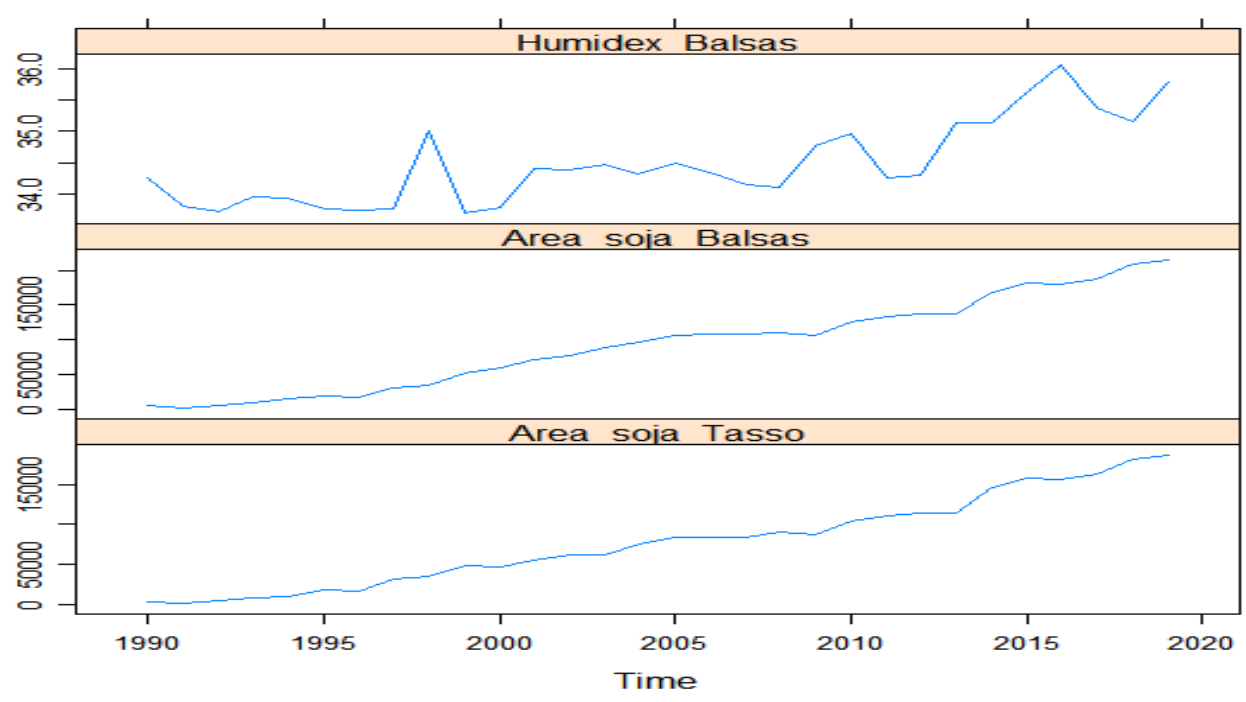

Figure 8- Humidex $\left({ }^{\circ} \mathrm{C}\right)$, soy area in Balsas and Tasso Fragoso in Hectares.

In order to verify the influence of largescale climate such as El Niño and La Niña events on the Humidex index oscillation, kernel density analyses was applied over both data series. 
It can be seen in Figure 9 that the 2016 El Niño was more intense than the 1998 El Niño with a Humidex index exceeding $40{ }^{\circ} \mathrm{C}$. Cunha et al. (2015b) showed that the drought from 2012 to 2013, affected about $85 \%$ of the Brazilian semiarid region, affecting precipitation, soil moisture, recovery and the effects of vegetation memory. Kogan confirms that El Niño2015/2016 was much stronger than the extreme event of 1997-1998 affecting different regions of the globe. It was observed that in the La Nina event in 2011, the Humidex was thermally more comfortable than La Niña of 2018, similar to the El Niño in 1998. 


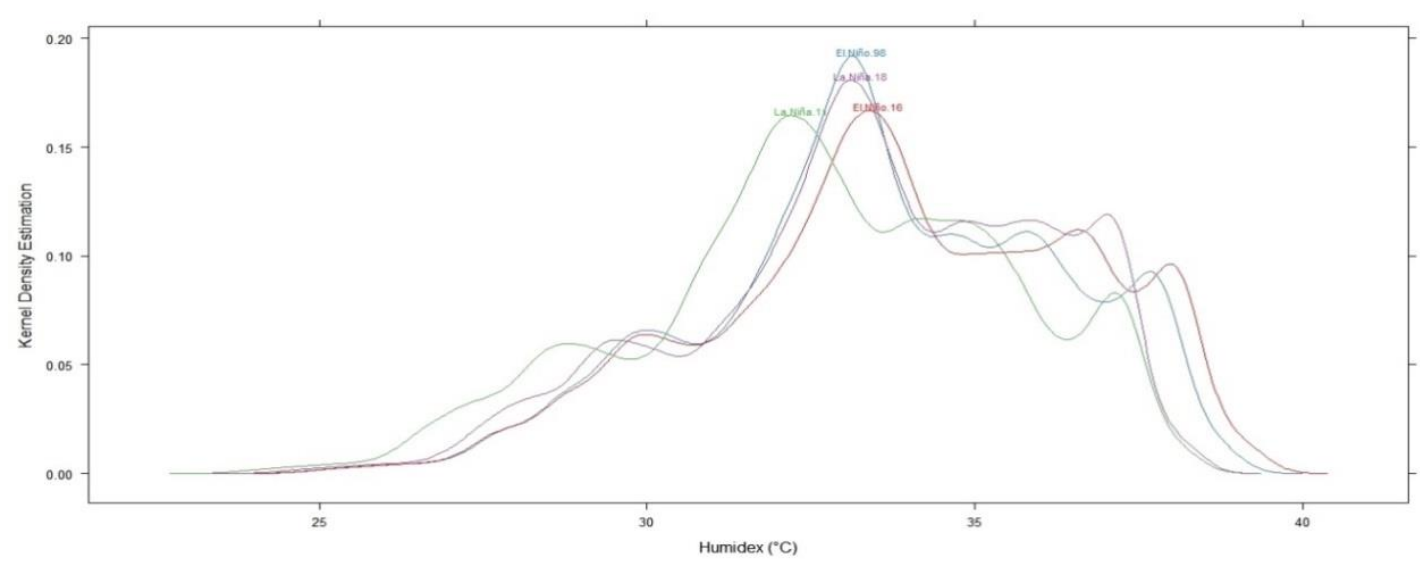

Figure 9 - Kernell density of Humidex index during El Niño (1998 and 2016) and La Niña (2011, 2018).

\section{Conclusions}

This study aimed to study the Humidex index on different scales such as hourly, monthly, seasonal and annual and their respective trends. It was noticed that the MATOPIBA region was the region that stood out the most with positive discomfort trends, as well as the region with the highest Humidex indexes. In that, it was observed that the night time has a positive trend on NEB, especially on MATOPIBA. In addition to the hourly scale, it was also found that on the monthly, seasonal and annual scale, this region of MATOPIBA has a highlight. This is due to the fact that the replacement of the natural forest by agricultural production, in which, it directly affects the energy balance in this region. It was observed that the NEB's east coast region was influenced by the Atlantic Ocean.

It was found that during the daytime, the northern region of the NEB has the highest rates of thermal discomfort and the central-southern region of the NEB, during the nighttime, has the most thermally comfortable rates.

It was observed that the Humidex index in the range of $5^{\circ} \mathrm{S}$ presents from October to May more uncomfortable with indexes above $35^{\circ} \mathrm{C}$. Note that the NEB coast has a relatively constant index throughout the year due to the influence of the ocean. Between $10^{\circ} \mathrm{S}$ and $20^{\circ} \mathrm{S}$, on the continental NEB region, the Humidex index declines from January $\left(29^{\circ} \mathrm{C}\right)$ to August $\left(>23^{\circ} \mathrm{C}\right)$, mainly on the Chapada Diamantina and central region of the state of Bahia and some other high altitude regions as in Pernambuco, Alagoas and Paraíba, returning from September. This is due to the position of the sun, altitude and weather and climate factors.

It was found that in the La Niñaperiod it was considered relatively more comfortable thermally, whereas in the El Niño period it was reversed. The reduction and increase in precipitation on the NEB due to El Niño and La Niña led to the attenuation of the Humidex index.

Therefore, the Humidex index was studied and the attenuation of this index in relation to the time-spatial scale was altered due to meteorological systems, change due to the modification of land use and attenuation due to the El Niño and La Niña phenomena.

\section{Acknowledgements}

The authors are grateful to the providers of the data used in this study: ERA5 dataset distributed by ECMWF.

\section{References}

Ailton A. de Carvalho, Abelardo A. de A. Montenegro,Hernande P. da Silva, Iug Lopes,José E. F. de Morais, Thieres G. F. da Silva. Trends of rainfall and temperature in Northeast Brazil. Revista Brasileira de Engenharia Agrícola e Ambiental, v.24, n.1, p.15-23, 2020

Amasuomo, T.T.; Amasuomo, J.O., 2016. Perceived Thermal Discomfort and Stress 
Behaviours Affecting Students' Learning in Lecture Theatres in the Humid Tropics. Buildings, 6, 18.

Angelini, L.P., Silva, P. C. B.S., Fausto, M. A., Machado, N. G., Biudes, M. S., 2017. Balanço de Energia nas Condições de Mudanças de Uso do Solo na Região Sul do Estado de Mato Grosso. Revista Brasileira de Meteorologia, 32(3), 353-363. https://doi.org/10.1590/010277863230003

Bao-Jie He, Lan Ding, Deo Prasad, Outdoor thermal environment of an open space under sea breeze: A mobile experience in a coastal city of Sydney, Australia, Urban Climate, Volume 31, 2020b, 100567, ISSN 2212-0955, https://doi.org/10.1016/j.uclim.2019.100567.

Bao-Jie He, Lan Ding, Deo Prasad, Relationships among local-scale urban morphology, urban ventilation, urban heat island and outdoor thermal comfort under sea breeze influence, Sustainable Cities and Society, Volume 60, 2020a, 102289, ISSN 2210-6707, https://doi.org/10.1016/j.scs.2020.102289.

Brake, D.J., Bates, G.P., 2003. Fluid losses and hydration status of industrial workers under thermal stress working extended shiftsOccupational and Environmental Medicine; 60:90-96.

Brito, S.S.; Cunha, A.P.; Cunningham, C.C.; Alvalá, R.C.; Marengo, J.A.; Carvalho, M.A.,2018. Frequency, duration and severity of drought in the Semiarid Northeast Brazil region. Int. J. Climatol., 38, 517-529

Buitrago, M.F., Groen, T. A., Hecker, C. A., Skidmore, A. K. 2016. Changes in thermal infrared spectra of plants caused by temperature and water stress, ISPRS Journal of Photogrammetry and Remote Sensing, Volume 111, Pages 22-31. https://doi.org/10.1016/j.isprsjprs.2015.11.003.

Cabral Júnior, J.B., Silva, C.M.S.e., de Almeida, H.A. et al., 2019. Detecting linear trend of reference evapotranspiration in irrigated farming areas in Brazil's semiarid region. Theor Appl Climatol 138, 215-225. https://doi.org/10.1007/s00704-019-02816-w
Cai, J., 2019. humidity: Calculate Water Vapor Measures from Temperature and Dew Point. $\mathrm{R}$ package version 0.1.5.

Castelhano F. J., 2017. /Laboclima - Universidade Federal do Paraná (2017). ThermIndex: Calculate Thermal Indexes. R package version 0.2.0. https://CRAN.Rproject.org/package $=$ ThermIndex

Cucchi, M., Weedon, G. P., Amici, A., Bellouin, N., Lange, S., Müller Schmied, H., Hersb ach, H., and Buontempo, C., 2020.: WFDE5: biasadjusted ERA5 reanalysis data for impact studies, Earth Syst. Sci. Data, 12, 2097-21 20, https://doi.org/10.5194/essd-12-2097-2020.

Cunha AP et al (2015b) Monitoring vegetative drought dynamics in the Brazilian semiarid region. Agric For Meteorol 214-215:494-505.

Cunha A.P.M.A., Alvalá, R.C.S., Kubota, P.Y., Vieira, R.M.S.P (2015a) Impacts of land use and land cover changes on the climate over Northeast Brazil. Atmos Sci Lett 16:219-227. https://doi.org/10.1002/as12.543

Cunha, A.P.M.A., Tomasella, J., Ribeiro-Neto, G.G., Brown, M., Garcia, S.R., Brito, S.B., Carvalho, M.A., 2018. Changes in the spatialtemporal patterns of droughts in the Brazilian Northeast. Atmos. Sci. Lett., 19,855-862.

d'Ambrosio Alfano FR, Palella BI, Riccio G (2007) The role of measurement accuracy on the heat stress assessment according to ISO 7933: 2004. WIT Transactions on Biomedicine and Health 11, 115-24.

de Medeiros, F.J., de Oliveira, C.P. \& Torres, R.R. Climatic aspects and vertical structure circulation associated with the severe drought in Northeast Brazil (2012-2016). Clim Dyn 55, 2327-2341 (2020). https://doi.org/10.1007/s00382-020-05385-1

Di Napoli, C.; Barnard, C.; Prudhomme, C.; Cloke, H.L.; Pappenberger, F. ERA5-HEAT: A global gridded historical dataset of human thermal comfort indices from climate reanalysis. Geosci. Data J. 2020, 1-9.

Domínguez-Amarillo, S.; Fernández-Agüera, J.; González, M.M.; Cuerdo-Vilches, T. 
Overheating in Schools: Factors Determining Children's Perceptions of Overall Comfort Indoors. Sustainability 2020, 12, 5772.

Evans, J.S., 2020. _spatialEco_. R package version $\quad 1.3-1, \quad<U R L$ : https://github.com/jeffreyevans/spatialEco>.

Fedorova, N., Levit, V., Cavalcante, L. C. V., 2020. Impacts of Tropical Cyclones in the Northern Atlantic on Adverse Phenomena Formation in Northeastern Brazil, Current Topics in Tropical Cyclone Research [Working Title], 10.5772/intechopen.82936.

Fedorova, N., Levit, V., Silveira, M.H.S., Pontes Da Silva, B.F., Amiranashvili, A.G., 2009. Mesoscale Convective Complexes on the Northeastern Coast of Brazil. Journal of the Georgian Geophysical Society, Issue B: Physics of Atmosphere, Ocean and Space Plasma, 13B, 36-49.

Forkel, M., Carvalhais, N., Verbesselt, J., Mahecha, M. D., Neigh, C., Reichstein, M., 2013. Trend Change Detection in NDVI Time Series: Effects of Inter-Annual Variability and Methodology. Remote Sensing, 5(5), 21132144.

Forkel, M., Migliavacca, M., Thonicke, K., Reichstein, M., Schaphoff, S., Weber, U., Carvalhais, N., 2015. Co-dominant water control on global inter-annual variability and trends in land surface phenology and greenness. Global Change Biology, 21(9), 3414-3435.

García, M.M., Martín, J.R., Soriano, L.R., Dávila, F.P.,2015. Observed impact of land u ses and soil types on cloud-to-ground lightning in Castilla-Leon (Spain). Atmospheric Research. Volume 166, 2015, Pages 233-238. https://doi.org/10.1016/j.atmosres.2015.07.009

Gaspari, J., Fabbri, K., Lucchi, M., 2018.The u se of outdoor microclimate analysis to support decision making process: Case study of Bufalini square in Cesena. Sustain able Cities and Society. Volume 42, October 2018, Page s 206-215.

https://doi.org/10.1016/j.scs.2018.07.015
Giannini, A., Chiang, J. C. H., Cane, M. A., Kushnir, Y., Seager, R., 2001. "The ENSO teleconnection to the tropical Atlantic oce an: Contributions of the remote and local SSTs to rainfall variability in the tropical Americas," J. Clim. 14(24), 4530-4544. https://doi.org/10.1175/15200442(2001)014<4530:TETTTT>2.0.CO;2

Hastenrath, S. and Heller, L.,1977. Dynamic of Climatic Hazards in Northeast Brazil. Quarterly Journal of the Royal Meteorological Society, 110, 411-425. http://dx.doi.org/10.1002/qj.4971 1046407

He, B.J., Ding, L., Prasad, D. Outdoor thermal environment of an open space under sea breeze: A mobile experience in a coastal city of Sydney, Australia, Urban Climate, Volume 31, 2020b, 100567, ISSN 2212-0955, https://doi.org/10.1016/j.uclim.2019.100567.

He, B.J., Ding, L., Prasad, D. Relationships among local-scale urban morphology, urban ventilation, urban heat island and outdoor thermal comfort under sea breeze influence, Sustainable Cities and Society, Volume 60, 2020a, 102289, ISSN 2210-6707, https://doi.org/10.1016/j.scs.2020.102289.

Hersbach, H., 2017. ERA5: the new reanalysis of weather and climate data. ECMWF Science blog

Hersbach, H. et al. Global reanalysis: goodbye ERA-Interim, hello ERA5. ECMWF Newsletter 17-24 (2019).

Hersbach, H. et al., 2020. The ERA5 global reanalysis. Q J R Meteorol Soc 1- 51, https://doi.org/10.1002/qj.3803.

Hijmans, R.J., 2020. raster: Geographic Data Analysis and Modeling. R package version 3.3-13. https://CRAN.Rproject.org/package=raster

Hirota, M., Oyama, M.D., Nobre, C., 2011. Concurrent climate impacts of tro pical South America land-cover change. Atmos. Sci. Let. 12: 261-267.

Huimin Liu, Bo Huang, Sihang Gao, Jiong Wang, Chen Yang, Rongrong Li, Impacts of the 
evolving urban development on intra-urban surface thermal environment: Evidence from 323 Chinese cities, Science of The Total Environment,Volume 771, 2021, 144810, ISSN 0048-9697, https://doi.org/10.1016/j.scitotenv.2020.14481 0 .

\section{IBGE, 2020 .}

https://censo2010.ibge.gov.br/sinopse/index.ph $\mathrm{p}$ ?dados $=4 \& u f=00$

Kendall, M.G.,1975. Rank Correlation Methods. Griffin, London. Kogan F.N., Guo, W., 2017. Strong 2015-2016 El Niño and implication to global ecosystems from space data. Int $\mathbf{J}$ Remote Sens 38(1):161-178.

Kousky, V.E. and Gan, M.A., 1981. Upper Tropospheric Cyclonic Vortices in the Tropical South Atlantic. Tellus, 33, 538-551. http://dx.doi.org/10.1111/j.2153-

3490.1981.tb01780.x

Krishnamurthy, V., Misra, V., 2010. Observed ENSO teleconnections with the SouthAmerican monsoon system. Atmos. Sci. Let. 11: 7-12.

Kulikova, I., Fedorova, N., Levit, V., Cordeiro, E. S., 2014. Sea Surface Temperature Anomaly and Precipitation Distribution in the Alagoas State of the Brazilian Northeast, Natural Science, 10.4236/ns.2014.614104, 06, 14, (1159-1178).

Lamigueiro, O.P., Hijmans, R., 2020, rasterVis. R package version 0.48. Neuwirth, E., 2014. RColorBrewer: ColorBrewer Palettes. R package. version 1.1-2. https://CRAN.Rproject.org/package $=$ RColorBrewer

Li, Xian-Xiang, 2020. Heat wave trends in Southeast Asia during 1979-2018: The impact of humidity, Science of The Total Environment, 10.1016/j.scitotenv.2020.137664， 721， (137664).

Liu, H., Huang, B., Gao, S., Wang, J., Yang, C., R. Li, R., Impacts of the evolving urban development on intra-urban surface thermal environment: Evidence from 323 Chinese cities, Science of The Total Environment,Volume 771, 2021, 144810 ,
ISSN

0048-9697, https://doi.org/10.1016/j.scitotenv.2020.14481 0 .

Mann, H.B., 1945. Nonparametric tests against trend. Econometrica, v.13, n. 3, p.245-259.

Marçal, N.A., Silva, R.M., Santos, A.G., Santos, J.S., 2019. Analysis of the environmental thermal comfort conditions in public squares in the semiarid region of northeastern Brazil. Building and Environment. Volume 152, Pages 145-159.

https://doi.org/10.1016/j.buildenv.2019.02.016

Marengo J.A. et al., 2019. Increase Risk of Drought in the Semiarid Lands of Northeast Brazil Due to Regional Warming above $4{ }^{\circ} \mathrm{C}$. In: Nobre C., Marengo J., Soares W. (eds) Climate Change Risks in Brazil. Springer, Cham. https://doi.org/10.1007/978-3-31992881-4_7

Marengo, J.A., Cunha, A.P.M.A., Nobre, C.A. et al. Assessing drought in the drylands of northeast Brazil under regional warming exceeding $4{ }^{\circ} \mathrm{C}$. Nat Hazards 103, 2589-2611 (2020). https://doi.org/10.1007/s11069-02004097-3

Martens, B., Schumacher, D. L., Wouters, H., Muñoz-Sabater, J., Verhoest, N. E. C., and Miralles, D. G., 2020: Evaluating the landsurface energy partitioning in ERA 5, Geosci. Model Dev., 13, 4159-4181, https://doi.org/10.5194/gmd-13-4159-2020.

Masterton, J.M., Richardson, F.A., 1979. HUMIDEX: a method of quantifying human discomfort due to excessive heat and humidity. CLI 1-79. 1-45, Environment Canada, Downside Ontario.

Matallah, M.E.; Alkama, D.; Teller, J.; Ahriz, A.; Attia, S. Quantification of the Outdoor Thermal Comfort within Different Oases Urban Fabrics. Sustainability 2021, 13, 3051. https://doi.org/10.3390/su13063051

Medeiros, F. J., Oliveira, C. P., C. M. Santos e Silva, Araújo, J. M., 2020. Numerical simulation of the circulation and tropical teleconnection mechanisms of a severe drought event (2012-2016) in Northeastern Brazil, 
Climate Dynamics, 10.1007/s00382-02005213-6.

Mistry, M.N., 2020. A High Spatiotemporal Resolution Global Gridded Dataset of Historical Human Discomfort Indices. Atmosphere, 11,835.

Molion, L.C.B., Bernardo, S.O., 2002. Uma revisão da dinâmica das chuvas no Nordeste Brasileiro. Revista Brasileira de Meteorologia, 17, 1-10.

Moura, Geber B. de A. et al . Relação entre a precipitação do leste do Nordeste do Brasil e a temperatura dos oceanos. Rev. bras. eng. agríc. ambient., Campina Grande, v. 13, n. 4, p. 462-469, Aug. 2009 . Available from $<$ http://www.scielo.br/scielo.php?script=sci_art text\&pid=S1415-

$43662009000400014 \& \operatorname{lng}=\mathrm{e} n \& \mathrm{nrm}=\mathrm{iso}>$. access on $13 \quad$ May 2021. http://dx.doi.org/10.1590/S141543662009000400014.

Naika Meili, Juan Angel Acero, Nadav Peleg, Gabriele Manoli, Paolo Burlando, Simone Fatichi, Vegetation cover and plant-trait effects on outdoor thermal comfort in a tropical city, Building and Environment, Volume 195, 2021, 107733, ISSN 0360-1323 https://doi.org/10.1016/j.buildenv.2021.107733

Narisma, G. T., A. J. Pitman, 2003: The Impact of 200 Years of Land Cover Change on the Australian Near-Surface Climate. J. Hydrometeor., 4, 424-436, https://doi.org/10.1175/15257541(2003)4<424:TIOYOL>2.0.CO;2.

Pereira, C.T., Masiero, É. \& Bourscheidt, V. Socio-spatial inequality and its relationship to thermal (dis)comfort in two major Local Climate Zones in a tropical coastal city. Int J Biometeorol (2021). https://doi.org/10.1007/s00484-021-02099-9

Pohlert, T., 2020. trend: Non-Parametric Trend Tests and Change-Point Detection. R package version 1.1.2. https://CRAN.Rproject.org/package $=$ trend

$\mathrm{R}$ Core Team, 2020. R: A language and environment for statistical computing. $\mathrm{R}$
Foundation for Statistical Computing, Vienna, Austria. URL https://www.R-project.org/.

Rafaela Lisboa Costa, Gustavo Macedo de Mello Baptista, Heliofábio Barros Gomes, Fabrício Daniel dos Santos Silva, Rodrigo Lins da Rocha Júnior, Mozar de Araújo Salvador, Dirceu Luís Herdies, Analysis of climate extremes indices over northeast Brazil from 1961 to 2014, Weather and Climate Extremes, Volume 28, 2020, 100254, ISSN 2212 -0947, https://doi.org/10.1016/j.wace.2020.100254. DOI: http://dx.doi.org/10.1590/18071929/agriambi.v24n 1p15-23

Richa Sharma, Lolita Pradhan, Maya Kumari, Prodyut Bhattacharya, Assessing urban heat islands and thermal comfort in Noida City using geospatial technology, Urban Climate, Volume 35, 2021, 100751, ISSN 22 12 -0955, https://doi.org/10.1016/j.uclim.2020.100751.

Rita Marcia da Silva Pinto Vieira, Javier Tomasella, Alexandre Augusto Barbosa, Silvia Palotti Polizel, Jean Pierre Henry Balbaud Ometto, Fabrícia Cristina Santos, Yara da Cruz Ferreira, Peter Mann de Toledo, Land degradation mapping in the MATOPIBA region (Brazil) using remote sensing data and decision-tree analysis, Science of The Total Environment, Volume 782, 2021, 146900, ISSN 0048-9697, https://doi.org/10.1016/j.scitotenv.2021.14690 0 .

Rodrigues, L.R.L., Fedorova, N. and Levit, V., 2010. Adverse Meteorological Phenomena Associated with Low Level Baric Troughs in the Alagoas State, Brazil, in 2003. Atmospheric Science Letters, 11, 204-209. http://dx.doi.org/10.1002/asl.273

Rodrigues, R. R., McPhaden, M. J., 2014. "Why did the 2011-2012 La Niña cause a severe drought in the Brazilian Northeast?," Geophys. Res. Lett. 41(3), 1012-1018. https://doi.org/10.1002/2013GL058703

Salvador, M.D.A., de Brito, J.I.B., 2018. Trend of annual temperature and frequency of extre me events in the MATOPIBA region of Brazil. Theor Appl Climatol 133, 253-261. https://doi.org/10.1007/s00704-017-2179-5.

Silva, W. T. C., Cavalcante, G. H. 
Salvador, M.d.A., de Brito, J.I.B. Trend of annual temperature and frequency of extreme events in the MATOPIBA region of Brazil. Theor Appl Climatol 133, 253-261 (2018). https://doi.org/10.1007/s00704-017-2179-5

Sanagar Darbani, E., Monsefi Parapari, D., Boland, J. et al. Impacts of urban form and urban heat island on the outdoor thermal comfort: a pilot study on Mashhad. Int $\mathbf{J}$ Biometeorol (2021). https://doi.org/10.1007/s00484-021-02091-3.

Schwarz, D., Rouphael, Y., Colla, G., Venema, J. H. 2010.Grafting as a tool to improve tolerance of vegetables to abiotic stresses: Thermal stress, water stress and organic pollutants, Scientia Horticulturae, Volume 127, Issue 2, Pages 162-171. https://doi.org/10.1016/j.scienta.2010.09.016.

Silva, J.S.S., Silva, R.M., Santos, C.A.G., 2018. Spatiotemporal impact of land use/land cover changes on urban heat islands: A case study of Paço do Lumiar, Brazil. Volume 136, Pages 279-292.

https://doi.org/10.1016/j.buildenv.2018.03.041

Sisniega, D.P.S., García, M.M., Menéndez, S.F., Soriano, L.R., Dávila, F.B., 2018. Evidence for the influence of land uses and soil types on cloud-to-ground lightning activity in Asturias
(Spain). Atmospheric Research. Volume 203, Pages $62-67$ https://doi.org/10.1016/j.atmosres.2017.11.025

Sokol, N.J., Rohli, R.V., 2018. Land cover, lightning frequency, and turbulent fluxes over Southern Louisiana. Applied Geography. Volume 90, Pages 1-8. https://doi.org/10.1016/j.apgeog.2017.11.003

Subhashinia, S., Thirumaran, K., 2018. A passive design solution to enhance thermal comfort in an educational building in the warm humid climatic zone of Madurai. Journal of Building Engineering. Volume 18, July 2018, Pages 395-407. https://doi.org/10.1016/j.jobe.2018.04.014

Tarek, M., Brissette, F. P., Arsenault, R., 2020: Evaluation of the ERA5 reanalysis as a potential reference dataset for hydrological modelling over North America, Hydrol. Earth Syst. Sci., 24, 2527-2544, https://doi.org/10.5194/hess-24-2527-2020.

Thom, E.C., Bosen, J.F., 1959. The discomfort index. Weatherwise 12, 57-60.

Vitolo, C., Di Giuseppe, F., Barnard, C. et al., 2020. ERA5-based global meteorological wildfire danger maps. Sci Data 7, 216. https://doi.org/10.1038/s41597-020-0554-z 